\title{
Low Cost Flywheel Energy Storage for a Fuel Cell Powered Transit Bus
}

\author{
C.S Hearn ${ }^{1}$, M.M. Flynn ${ }^{1}$, M.C. Lewis ${ }^{1}$, R.C. Thompson ${ }^{1}$, B.T. Murphy ${ }^{1}$, R.G. Longoria ${ }^{2}$ \\ 1) The University of Texas at Austin - Center for Electromechanics \\ 10100 Burnet Rd. EME 133 \\ Austin, TX 78758 \\ 2) The University of Texas at Austin \\ 1 University Station, R2200 \\ Austin, TX 78712
}

\begin{abstract}
This paper presents work that was performed to design a compact flywheel energy storage solution for a fuel cell powered transit bus with a focus on commercialization requirements. For hybrid vehicle applications, flywheels offer much higher power densities than conventional batteries. The presented design attempts to maximize the use of lower-cost technologies. The rotor relies primarily on steel for the flywheel structure, and emphasis is placed on size reduction for vehicle packaging advantages Simulations of bus configurations on measured routes was performed using PSAT to correctly size the flywheel energy storage system.
\end{abstract}

\section{INTRODUCTION}

The goal of this program is to design a Flywheel Energy Storage System (FESS) for integration into a fuel cell powered bus. Traditionally, the energy storage requirement for conventional and fuel cell hybrid buses has been satisfied by chemical batteries. This is in part due to the low initial purchase expense, high energy density, as well as the high level of familiarity engineers possess compared to newer technologies. However, batteries have a number of disadvantages such as limited cycle life, maintenance, conditioning requirements, and modest power densities which have been improved upon by newer technologies such as ultracapacitors and high-speed flywheels. Flywheels in particular offer very high reliability and cycle life without degradation, reduced ambient temperature concerns, and construction free of environmentally harmful materials. Integration of these technologies is well suited for urban bus applications due to the traditional bus route cycles which contain large amounts of deceleration and acceleration for potential energy recovery and re-usage. In addition, buses have high public visibility, providing an attractive platform for demonstrating safe and effective implementation of alternative energy technologies.

There has been much work done in the past to use flywheel technology for public transportation on buses. The Dutch company CCM, Centre for Concepts in Mechatronics, has produced flywheels for a number of hybrid vehicle applications for public transportation since 1986 [1]. The complete flywheel energy system they produced is termed EMAFER, "Electro-Mechanical Accumulator for Energy Re-use". Technologies used in their flywheel designs include, carbon fiber composites, permanent magnet motor-generators, and power electronic controls. In 1998, CCM incorporated a 200 $\mathrm{kW}, 2 \mathrm{kWh}$ flywheel system on a trolleybus powered by a 40 kW LPG engine. In 2001, ULEV-TAP I was a 30 ton service tram which solely used a $300 \mathrm{~kW}$, 4kWh CCM flywheel system for propulsion. The flywheel system was recharged at tramstops.

In 2005 the Fraunhofer Institute for Transport and Infrastructure developed an airport shuttle known as the AutoTram, The AutoTram is an articulated $18 \mathrm{~m}$ long bus that can be power by an $80 \mathrm{~kW}$ hydrogen fueled Ballard PEM fuel cell or a $180 \mathrm{~kW}$ diesel engine, with an EMAFER RoV-II flywheel energy system, developed by CCM, for energy storage [2]. The AutoTram can operate as a diesel electric with flywheel energy storage or a fuel cell powered tram with flywheel energy storage. The flywheel system is capable of delivering up to $4 \mathrm{kWh}$ of energy and providing $200 \mathrm{~kW}$ of continuous power. The flywheel operates at 25,000 r/min and has an expected life of 150,000 hrs.

The University of Texas, Center for Electromechanics, UTCEM, developed and tested a high speed composite flywheel for an Advanced Technology Transit Bus. This flywheel operated at 40,000 r/min and could deliver $844 \mathrm{Wh}$ at a power rating of $150 \mathrm{~kW}$. Road testing of the bus revealed acceleration time to $75 \mathrm{~km} / \mathrm{h}$ was reduced by a factor of two with a simultaneous reduction in engine power of $25 \%$ [3].

Although the flywheel developed by UT-CEM demonstrated marked improvement in bus performance, the use of magnetic bearings, an all composite flywheel, and a large gimbal made it unappealing from a commercial aspect with respect to cost and size. This article describes the development of a new flywheel design that utilizes steel rotors and rolling element ball bearings to reduce cost and complexity. Simulations using PSAT (Powertrain Simulation Analysis Toolkit) were used to help formulate energy storage and power requirements for this new flywheel design. This paper presents the PSAT simulations used to size the flywheel requirements, a comparison of three different design concepts to meet the flywheel requirements, and development of the final flywheel design.

\section{BUS PERFORMANCE SIMULATIONS}

The proposed flywheel energy storage system is designed for use on a $12 \mathrm{~m}$ fuel cell passenger bus which operates in an 
urban setting. In order to determine power and energy storage requirements for the flywheel, modeling of a bus was performed using PSAT, a vehicle simulator developed by Argonne National Laboratories. PSAT is a forward looking modeling tool that enables the construction and analysis of vehicle powertrain models by integrating the capabilities of Matlab, Simulink, and Stateflow.

The bus used in these simulations was based on the New Flyer D40FL design. A typical urban bus route was required for the analysis. The 1L North Lamar / South Congress route in Austin TX, serviced by Capital Metropolitan Transportation Authority, was selected as the route. This route was suggested by Capital Metro as one of the more demanding routes in Austin. The $1 \mathrm{~L}$ route is $30.9 \mathrm{~km}(19.2 \mathrm{mi})$ one way and serviced by Capital Metro 19 hours per day. Speed versus time data of a $20.5 \mathrm{~km}$ (12.8 mi) section of this route was recorded and consists of the most densely urban portion of the route. Route statistics are as follows:

- $\quad$ Maximum Speed: $20.0 \mathrm{~m} / \mathrm{s}(44.7 \mathrm{mi} / \mathrm{h})$

- $\quad$ Average Speed: $5.5 \mathrm{~m} / \mathrm{s}(12.3 \mathrm{mi} / \mathrm{h})$

- Acceleration: Max: $2.2 \mathrm{~m} / \mathrm{s}^{2}$, Average: $0.5 \mathrm{~m} / \mathrm{s}^{2}$

- Deceleration: Max: $2.6 \mathrm{~m} / \mathrm{s}^{2}$, Average: $0.6 \mathrm{~m} / \mathrm{s}^{2}$

- $\quad$ Percentage of cycle bus stopped: $28.0 \%$, Average 4.8 stops per mile

Fig. 1 shows the recorded measurements of speed vs. time as a conventional diesel bus follows this route.

The primary goal of the bus design from the simulations was to size the fuel cell and flywheel system so that the new bus configuration would meet or exceed the performance capability of a conventional diesel bus along the $1 \mathrm{~L}$ route. The bus simulations included auxiliary power losses which would be present including air conditioning and other electrical systems. A total of $25 \mathrm{~kW}$ of mechanical and $7.5 \mathrm{~kW}$ of electrical loads was applied to the models to simulate these losses. The

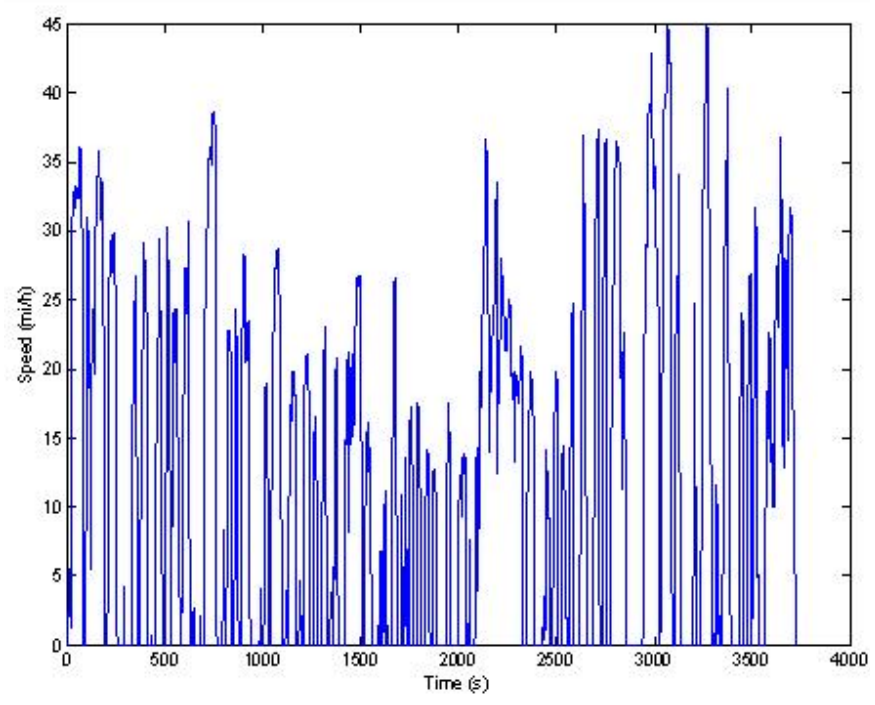

Figure 1: Speed profile of 1L North Lamar / South Congress bus route in Austin TX.
TABLE I

PERFORMANCE COMPARISON OF DIESEL BUS TO FUEL CELL BUS WITH FESS

\begin{tabular}{|l|c|c|c|}
\cline { 2 - 4 } \multicolumn{1}{c|}{} & Unit & Diesel Bus & $\begin{array}{c}\text { Fuel Cell Bus } \\
\text { with FESS }\end{array}$ \\
\hline $\begin{array}{l}\text { Fuel Economy } \\
\text { (Gasoline Equivalent) }\end{array}$ & $\mathrm{mi} / \mathrm{gal}$ & 2.78 & 3.61 \\
\hline $\begin{array}{l}\text { Fuel Mass Needed to } \\
\text { Complete 231.8 Daily } \\
\text { Miles }\end{array}$ & $\mathrm{kg}$ & $\begin{array}{c}236.8 \\
\text { (Diesel) }\end{array}$ & $\begin{array}{c}66 \\
\text { (Hydrogen) }\end{array}$ \\
\hline $\begin{array}{l}\text { Energy Consumed by } \\
\text { Vehicle During 231.8 } \\
\text { Miles }\end{array}$ & $\mathrm{kWh}$ & 2957 & 2199 \\
\hline $\begin{array}{l}\text { Prime Mover Average } \\
\text { Efficiency }\end{array}$ & $\%$ & 39.1 & 47.4 \\
\hline $\begin{array}{l}\text { Acceleration Time } \\
\text { from 0 - 10 mph }\end{array}$ & $\mathrm{s}$ & 2.3 & 3.9 \\
\hline $\begin{array}{l}\text { Acceleration Time } \\
\text { from 0 - 40 mph }\end{array}$ & $\mathrm{s}$ & 30.3 & 18.8 \\
\hline
\end{tabular}

simulation setup also assumes the bus is partially loaded with passengers and has a gross weight of $13,947 \mathrm{~kg}$.

To determine the energy storage requirements, preliminary iterations were performed simulating a $12 \mathrm{~m}$ diesel powered hybrid bus with a large, massless, energy storage device on board. The bus would only draw from the large energy storage device the energy and power required to complete the route. At the same time, the size of the primer mover was decreased until a reasonable balance was obtained between prime mover size and what a typical vehicle flywheel system could deliver. The simulation for an $85 \mathrm{~kW}$ prime mover showed that the energy storage requirement was $1.51 \mathrm{kWh}$ with $240 \mathrm{~kW}$ required to follow the route. In order to add margin for energy stored, the storage requirement was increased to $1.83 \mathrm{kWh}$, or about $20 \%$.

The next step involved modeling the bus with the proposed flywheel system and an $85 \mathrm{~kW}$ fuel cell system. A mass balance analysis showed that after removal of the diesel engine, mechanical transmission, and diesel tanks, along with the additions of the fuel cell, balance of plant, and high pressure hydrogen storage, the net change in mass was $+892 \mathrm{~kg}$. When performing the $1 \mathrm{~L}$ route, this increase in mass translated to more energy drawn from the flywheel system than the conventional bus experienced. Over the $1 \mathrm{~L}$ route, the fuel cell bus drew up to $1.72 \mathrm{kWh}$ from the flywheel system. An initial estimate of $100 \mathrm{~W}$ was also included in the flywheel model to account for bearing and windage losses.

The performance comparison of the fuel cell hybrid bus to a conventional non-hybrid diesel bus showed an equivalent fuel economy improvement of about 30\%, Table I. This improvement is largely due to the ability of the flywheels to capture and reuse regenerated energy during braking and from the higher inherent efficiency of the fuel cell compared to the diesel engine. The diesel bus demonstrate better low end acceleration, but the fuel cell bus showed that it could reach higher speeds, $8.9 \mathrm{~m} / \mathrm{s}(20 \mathrm{mi} / \mathrm{h})$ and above, faster than the diesel counterpart. This acceleration improvement is attributed to the extra power that the FESS is able to deliver to the drivetrain. 


\section{FLYWHEEL CONCEPTS}

Various flywheel concepts were developed to meet the energy storage and power requirement needs for the fuel cell bus. The following design goals were used in developing the concepts and considerations for the final design:

- Minimize cost and complexity

- Minimize weight and size

- $\quad$ Create size for vehicle packaging

- Maximize structural life

- Achieve 10 year service life

- $\quad$ Ensure passenger safety

One of the primary goals in developing these concepts was to reduce the complexity of the designs and limit the amount of exotic materials to reduce system costs. Included in this design consideration is the choice to go with rolling element ball bearings instead of magnetic bearings for each of the design concepts. Although the maximum potentials for energy storage are reduced, since maximum operating speeds must be lower, system costs would be lowered by removing the complexity of magnetic bearings. Magnetic bearings systems increase weight and volume, and still require rolling element "touch-down" bearings for when the shaft misaligns. In addition, more auxiliary components are required for controllers to operate the magnetic bearings. The design concepts were compared to one another and a final concept was chosen for detailed design development.

\section{A. Planetary Flywheel}

A multiple flywheel concept was developed for the FESS, Fig. 2. The goal behind this concept was to increase the energy storage potential of the flywheel system while also decreasing the inertia requirements of the individual flywheels. Reducing the inertia of the flywheels reduces the loading that the bearings experience due to gyroscopic effects while the bus pitches and rolls throughout its route. Typically gimbals are used to help manage these loads, but gimbals increase the volume and weight of the system. If the bearing load can be

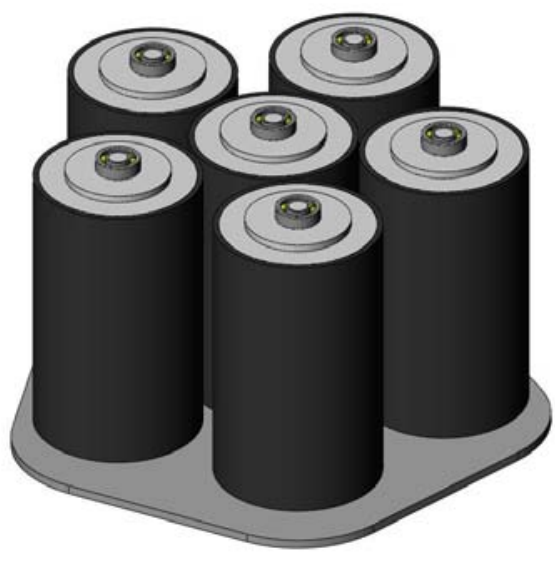

Figure 2: Planetary flywheel concept reduced to meet minimal bearing life requirements, then a gimbal may not be required.

The planetary flywheel concept consists of five equally sized flywheels, or "planets", that are magnetically coupled to a central flywheel, or "sun". The central flywheel is connected to a motor-generator to impart and withdraw energy from the system. Several papers report on magnetic coupling as used in magnetic gears, and these were valuable for evaluating this flywheel concept [4, 5, and 6].

Each flywheel in this concept consists of a 4340 steel tube, which serves as the primary structure and back iron. NdFeB permanent magnets are held in compression to the outer surface of the steel tube by a thin composite banding. The flywheels have a diameter of $150 \mathrm{~mm}$ and a length of $250 \mathrm{~mm}$. Through nested ring analysis, this particular structural design demonstrated a maximum operating speed of 28,000 r/min, which is limited by the bandings ability to retain the magnets in compression. This system was able to store 560 Wh.

An electromagnetic FE model of the flywheel planetary system was developed to study the coupling torque and losses induced in the permanent magnet flywheels. Of interest was the maximum torque at the interface between the flywheels and sun, because this would determine the maximum power the motor-generator would be able to deliver to the system. Additionally, eddy current losses in the magnets that contribute to inefficiencies and heating in the system were evaluated.

As found in [6] where a set of concentric magnetic gears was studied, the magnetic losses can be quite high. For this design, a higher pole count (20 poles pairs) was necessary in each flywheel to reduce losses and torque ripple. This system would result in a peak torque of $16.5 \mathrm{~N}-\mathrm{m}$ on the sun and losses of $14 \mathrm{~W}$ in the sun and $3 \mathrm{~W}$ in the planets. At the peak operational speed of $28,000 \mathrm{r} / \mathrm{min}$, the maximum power that could be pulled from the system is $48 \mathrm{~kW}$. This design concept is power limited due to both the maximum rotational speed the individual flywheel rotors could obtain, and the maximum torque that can be transmitted by magnetic torque coupling. The power transmitted is a linear function of speed since the maximum magnetic torque is constant throughout the operational speed range, 14,000 - 28,000 r/min.

\section{B. Disc Flywheel Concept}

The disc flywheel concept is based on more traditional flywheel designs, but integrates the motor-generator components into the flywheel rotor to reduce volume, Fig. 3. The permanent magnets of the motor-generator are retained onto the steel hub by a carbon fiber reinforced composite banding. The mass of the steel hub provides the main source of inertial energy storage in the system. The profile of the steel hub is based on modified equations for a constant stress disc which include a rim section for an increased radius of gyration [7].

Due to the increased inertia of the flywheel in this concept, a gimbal is now required to mitigate bearing loads to acceptable levels. A passive magnetic support has also been incorporated to alleviate the weight of the rotor from the ball bearings. 


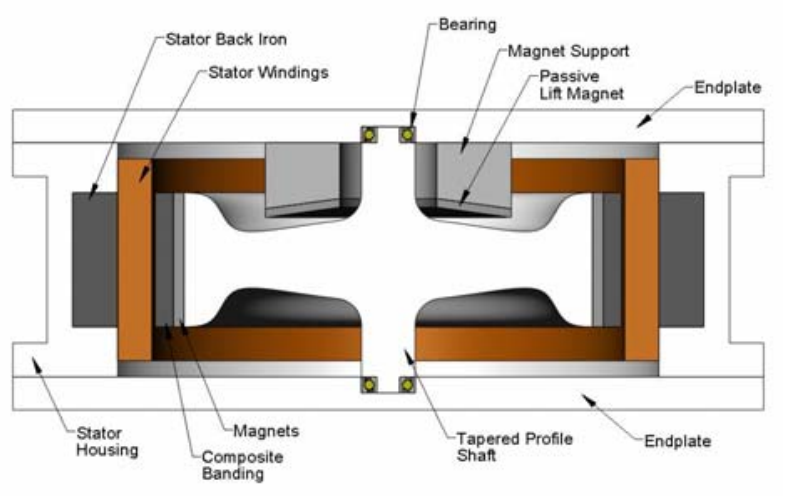

Figure 3: Disc flywheel concept

The flywheel has an outer diameter of $174 \mathrm{~mm}$ and stores a total of 617 Wh at a maximum operating speed of 21,000 r/min With a $75 \%$ depth of discharge, DOD, this flywheel can deliver $463 \mathrm{Wh}$ at $60 \mathrm{~kW}$ of power. A total of four flywheels would be required to meet the energy storage and power demands determined by the PSAT simulations. As with the planet flywheel design, this maximum operating speed is limited by the composite bandings ability to retain the magnets in compression to the steel flywheel. The ability to increase the composite's radial thickness to increase the stiffness of the banding is limited due to maximum air gap requirements for the motor-generator. Increasing the radial interference between the composite banding and magnets is also limited due to the maximum radial stresses that could be applied to the banding. Large radial stresses may induce creep which would result in a loss of preload.

In addition to a gimbal, a containment structure would be required to house the flywheel. The purpose of the containment structure is to mechanically absorb the kinetic energy of the flywheel in the event of an internal failure or vehicle accident. The thick stator back iron which surrounds the flywheel structure inherently adds an additional, natural containment structure to this flywheel design. Energy absorbing material would also be required in the axial directions.

\section{Steel Arbor Flywheel Concept}

The last flywheel option is a steel arbor which incorporates an inside out topography for the motor-generator, Fig. 4. The inside-out topography makes better use of the available space and increases the specific energy and power densities of the design. A set of three composite bandings controls the strain of the arbor through operation speeds.

The arbor flywheel has a diameter of $0.486 \mathrm{~m}$ and stores $1247 \mathrm{Wh}$ at a maximum operating speed of $18,000 \mathrm{r} / \mathrm{min}$. This flywheel design has a power output of $120 \mathrm{~kW}$. Only two units are required to meet the energy storage requirements, at 75\% DOD, and power requirements as determined by the PSAT analysis. This design will also require a gimbal to manage bearing loads and a more significant containment structure.

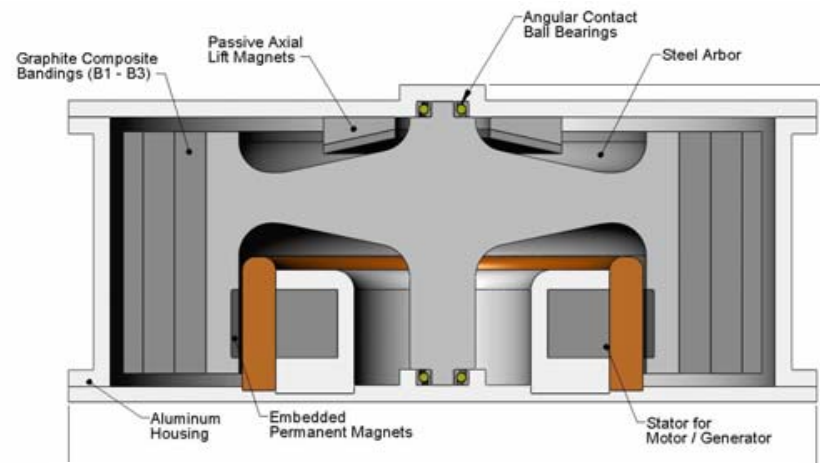

Figure 4: Arbor flywheel motor-generator concept

\section{Comparison of Design Concepts}

A brief comparison of the design concepts is shown in Table II. The masses and volumes used for the calculation of specific energy and power of each concept did not include structures for gimbal and containment. Although the planetary flywheel system would not require a gimbal, it would still require containment. The addition of these structures will alter the values in Table II, but the trends would remain the same.

The arbor flywheel concept shows significant advantages with respect to system size and energy storage capability. The arbor flywheel concept could be sized so that only two flywheels were required. This was possible by adding extra composite to the rim in order to make up inertia. Although, there was a design goal to limit the amount of composite used in the flywheel design, a tradeoff showed that it would be more beneficial and cost effective to increase the amount of carbon composite used, versus doubling (to four) the flywheels units required to meet energy storage requirements.

Efforts were made to increase the disc flywheel design to the same energy storage as the arbor flywheel, but limits were reached on magnet retention when trying to increase the flywheel diameter or speed. In addition, increasing flywheel length to increase inertia moved the inertia ratio of $\mathrm{I}_{\mathrm{p}} / \mathrm{I}_{\mathrm{T}}$ to a value close to one, which is not favorable for rotordynamics. The thickness of the composite material in the disc design is limited by the requirements for the motor-generator air-gap. The inertia of this design must be made primarily by the steel hub. The disc flywheel configuration required four units, each with $610 \mathrm{Wh}$ of total energy storage and $60 \mathrm{~kW}$ of power.

Due to the significant advantages of the arbor flywheel, this concept was chosen over the other two for the fuel cell bus FESS. The main advantage with this concept is that only two

TABLE II

COMPARISON OF FLYWHEEL DESIGN CONCEPTS

\begin{tabular}{|l|c|c|c|c|}
\hline & $\begin{array}{c}\text { Specific } \\
\text { Energy } \\
\text { Storage } \\
{[\mathrm{Wh} / \mathrm{kg}]}\end{array}$ & $\begin{array}{c}\text { Specific } \\
\text { Power } \\
{[\mathrm{kW} / \mathrm{kg}]}\end{array}$ & $\begin{array}{c}\text { Volumetric } \\
\text { Energy } \\
\text { Storage } \\
{\left[\mathrm{Wh} / \mathrm{m}^{\wedge} 3\right]}\end{array}$ & $\begin{array}{c}\text { Volumetric } \\
\text { Power } \\
{\left[\mathrm{kW} / \mathrm{m}^{\wedge} 3\right]}\end{array}$ \\
\hline $\begin{array}{l}\text { Planetary Flywheel } \\
\text { System }\end{array}$ & 2.74 & 0.237 & 6,881 & 596 \\
\hline Disc Flywheel & 3.41 & 0.331 & 11,242 & 1,093 \\
\hline Arbor Flywheel & 7.86 & 0.756 & 20,207 & 1,944 \\
\hline
\end{tabular}


flywheels would be required for the bus, overall reducing size and mass when containment and gimbal structures are added. The rest of this report will further discuss the arbor flywheel design.

\section{FINAL FLYWHEEL DESIGN}

\section{A. Structural Design and Fatigue Life}

Structural analysis was performed to evaluate the fatigue life of the steel arbor. Three composite bandings make up the rim which controls the strain growth of the steel arbor throughout the operation range of $9,000-18,000 \mathrm{r} / \mathrm{min}$. The design goal was to analytically demonstrate that the steel arbor could survive 10 million cycles in the operational range, and 1 million cycles from rest to full speed.

In order to increase the fatigue life of the steel arbor, and limit internal defects due to voids and inclusions, vacuum melted 4340 steel was chosen for the arbor material. Vacuum melted 4340 steel is produced by melting, alloying, and refining in a high vacuum, as opposed to air. This process results in significant improvement in the fatigue properties of 4340 steel because of reduction in gas content and number of nonmetallic inclusions. Since inclusions and voids can become crack initiation sites detrimental to fatigue life, the vacuum melted 4340 offers around 5 times the fatigue cycle life of airmelted 4340, [8].

In addition to material selection, the interferences of the composite bandings control hoop strain in the metallic rotor which controls fatigue life. The interferences of the composite bandings are designed so that the arbor experiences nearly complete stress reversal during normal operational mode, between 9,000 to $18,000 \mathrm{r} / \mathrm{min}$. From rest to $18,000 \mathrm{r} / \mathrm{min}$, the mean arbor stress is in compression. By biasing the stress oscillations to the compressive side, fatigue life can be increased since crack propagation is limited in the compressive state.

The final step to decrease stresses in the steel arbor and increase fatigue life was to limit the maximum tip speed of the

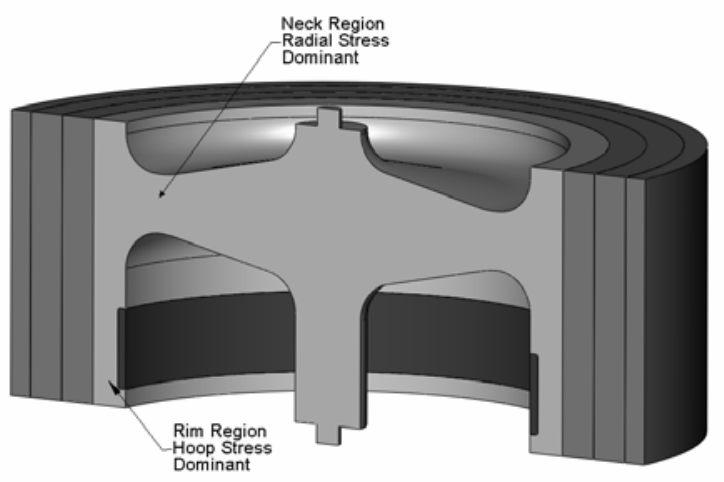

Figure 5: Isometric cutaway view of arbor flywheel with rim and neck sections labeled as areas of interest for structural analysis steel to $340 \mathrm{~m} / \mathrm{s}$. In addition to controlling the hoop strain of the steel, the three carbon composite graphite bandings serve to make up the inertia required for energy storage. The steel portion of the rotor contributes $56 \%$ of the inertial requirement for the flywheel.

Structural analysis was performed using ABAQUS FEA to determine the stress states at rest, at 9,000 $\mathrm{r} / \mathrm{min}$, and at 18,000 $\mathrm{r} / \mathrm{min}$ as an axisymmetric model. These speeds correspond to energy storage conditions of $0 \%$ SOC, 25\% SOC, and 100\% SOC, respectively. The two primary areas of concern are the stresses present in the rim and neck regions of the steel arbor, Fig. 5. The rim region is defined as the extension of the arbor rim which retains the magnets for the motor-generator. This region behaves like a steel tube in the nested ring stack-up with dominating hoop stresses. The neck region is the transition point where the arbor fans out and connects to the rim. Here, stresses are dominated by radial stress components since the structure is locally stiffer with respect to the interfering bandings.

The peak Von-Mises stress of $503 \mathrm{MPa}$ (73 ksi) occurs in the rim section of the steel arbor at rest. This stress is well below the yield stress of $1380 \mathrm{MPa}$ (200 ksi) for heat treated 4340 steel and is primarily a result of the compressive hoop strain imparted by the composite bandings. At full speed, the maximum Von-Mises stress is $338 \mathrm{MPa}$ (49 ksi) and also occurs as hoop-dominated components in the rim region of the steel arbor. The maximum excursions of radial stress in the neck regions range between -386 MPa (-56) ksi at rest and 303 MPa (44 ksi) at full speed. The hoop strains of the composite bandings reach $0.56 \%$ at full speed. IM7 composite bandings can operate up to $1 \%$ strain, so these bandings are well within safe operating conditions.

A safety factor of 2 was applied to the mean stress values and amplitudes for the steel arbor acquired from the FEA analysis to construct a Fatigue Life diagram using published data for vacuum melted 4340 steel [8], Fig. 6. The diagram shows that the flywheel will have a structural fatigue life of 1 million rest-full speed cycles which is limited by rim hoop stresses, and the flywheel can operate in excess of 10 million

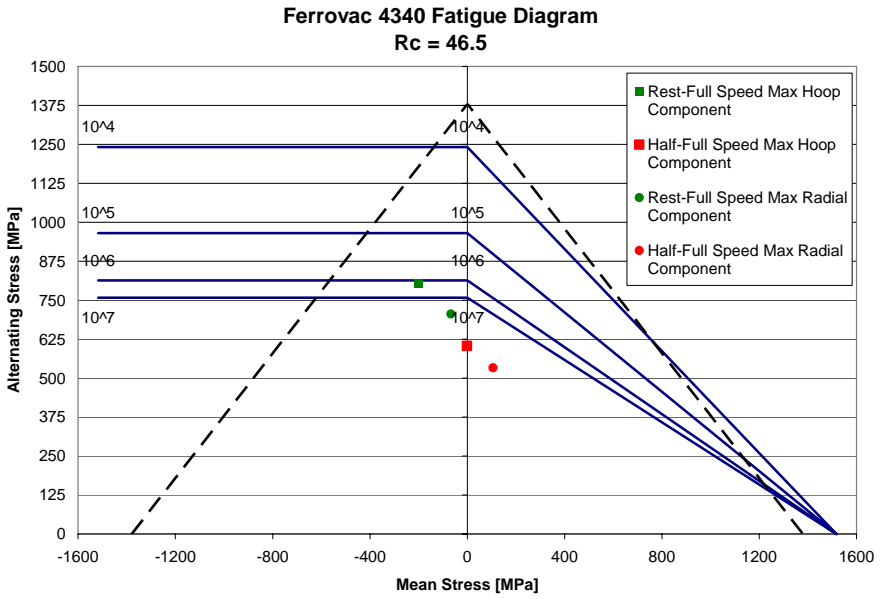

Figure 6: Fatigue Life diagram for steel arbor flywheel 


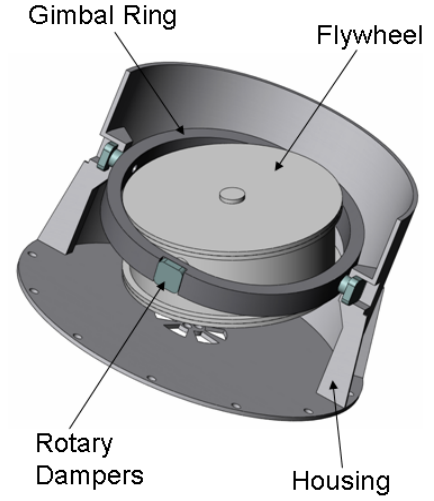

Figure 7: Flywheel gimbal

half-full speed cycles, which is the primary operating range. Since the mean stresses in these conditions are biased towards the compression, the estimates on fatigue life are conservative [9].

\section{B. Gimbal Performance and bearing life estimates}

Due to the larger inertia of the arbor flywheel design, a gimbal is required to isolate the flywheel from the motions of the bus and decrease the loads on the bearings. Without the use of a gimbal, bearing loads induced by gyroscopic reactions to pitch and roll movements of the bus can significantly reduce bearing life and make the design impractical for long term use.

The gimbal design for this flywheel application uses two pairs of pivot points to isolate the gimbal from bus movements and keep the axis of rotation vertical, Fig. 7. The gimbal allows a $15^{\circ}$ swing of the flywheel in any direction to accommodate vehicle motions. The center of gravity of the flywheel is offset below the gimbal axes to induce a natural pendulum spring force which acts to keep the flywheel vertical. The bearings in the gimbal system are pivot style bearings with a natural torsional spring rate. Damping for the gimbal is provided by a set of rotary dampers in each gimbal axis. Table III lists the appropriate flywheel and gimbal properties for the dynamic analysis of the system. Although spring rate and damping values for the bearings and dampers can be customized, values from off-the-shelf products were used for the initial simulation.

Simulations to determine torque reactions of the flywheel with respect to specified bus movement scenarios were performed with Mathcad. The scenarios that were considered included a sudden change to a $10^{\circ}$ banked road, a sudden bump or pothole, and a hard turn. The maximum road bank level was set to $10^{\circ}$ since a large transit bus chassis rarely sees angular deflections greater than $10^{\circ}$ due to a combination of road conditions and the vehicles own suspension [10].

For the most severe scenario, the vehicle suddenly hits a $10^{\circ}$ bank angle at $0.175 \mathrm{rad} / \mathrm{s}$ rate of change, and continues at this banked angle for the remainder of the simulation. A large transient torque spikes at approximately $190 \mathrm{Nm}$ (140 ft-lbs) then quickly drops to $135 \mathrm{Nm}$ (100 ft-lbs) followed by an exponential decay until the flywheel stabilizes at the new bank angle, Fig. 8. This condition represents a worst case scenario
TABLE III

FLYWHEEL AND GIMBAL PROPERTIES FOR RESPONSE ANALYSIS

\begin{tabular}{|l|c|l|c|}
\hline \multicolumn{2}{|c|}{ Flywheel Unit Properties } & \multicolumn{2}{c|}{ Gimbal Properties } \\
\hline \multicolumn{1}{|c|}{ Properties } & Value & \multicolumn{1}{|c|}{ Properties } & Value \\
\hline $\begin{array}{l}\text { Trans. Inertia, } \\
\text { rotor+stator [kg-m²] }\end{array}$ & 2.9 & $\begin{array}{l}\text { Torsional Stiffness } \\
{[\mathrm{N}-\mathrm{m} / \mathrm{rad}]}\end{array}$ & 904 \\
\hline $\begin{array}{l}\text { Polar Inertia, } \\
\text { rotor [kg-m²] }\end{array}$ & 2.5 & $\begin{array}{l}\text { Torsional Damping } \\
{[\mathrm{N} \text {-m-s/rad] }}\end{array}$ & 1356 \\
\hline $\begin{array}{l}\text { Trans. Inertia, } \\
\text { rotor [kg-m²] }\end{array}$ & 1.5 & $\begin{array}{l}\text { Angular Displacement } \\
{\left[{ }^{\circ}\right]}\end{array}$ & $+/-15$ \\
\hline Total Mass [kg] & 155 & $\begin{array}{l}\text { Free Precession Rate } \\
\text { at } 16,100 \mathrm{r} / \mathrm{min}[\mathrm{rad} / \mathrm{s}]\end{array}$ & 0.2 \\
\hline
\end{tabular}

that the flywheel would rarely experience on a bus [10]. For the next two cases which represent a pothole and a hard turn, the simulation shows that the gimbal is able to completely isolate the flywheel from these events and eliminate reaction loads on the bearings.

\section{Bearing Design Life Estimates}

Rolling element angular contact ball bearings were chosen for this flywheel application over magnetic bearings as a means to reduce cost and complexity of the system, but still provide sufficient performance and meet life requirements. The bearings have been designed to handle the torques derived from the gimbal motion analysis. The specified angular contact ball bearings have a $17 \mathrm{~mm}$ bore and a dynamic load rating of $11.6 \mathrm{kN}$. Modifications to off-the-shelf bearings would be required for the bearings to operate in the vacuum environment at the high operational speeds. An oil wick will provide an optimal amount of lubrication to the bearings.

The axial preload requirement on the ball bearings is driven by the $135 \mathrm{Nm}$ torque prediction from the gimbal analysis. An axial preload of $267 \mathrm{~N}$ (60lbs) was analyzed to be sufficient to keep the balls in compression with the maximum torque reaction at full speed, $18,000 \mathrm{r} / \mathrm{min}$. This axial load is the main
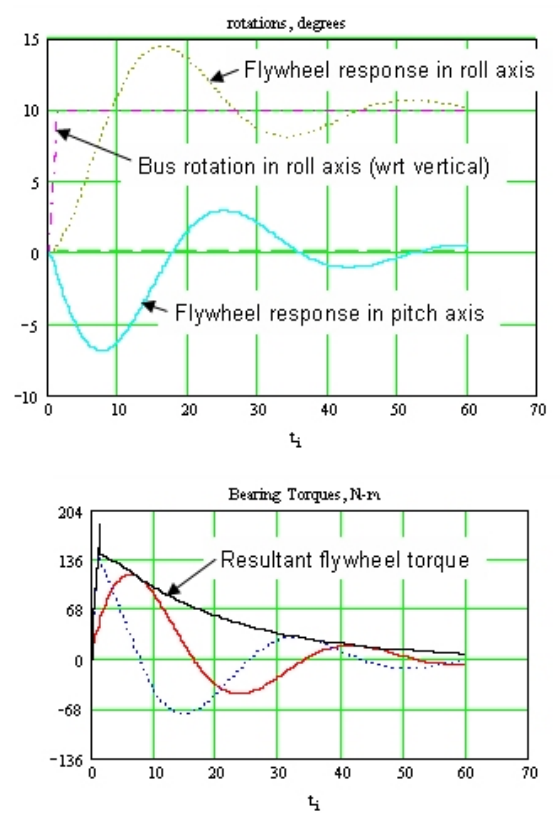

Figure 8: Gimbal and flywheel torque response to $10^{\circ}$ change in bank angle 
component of the bearing loads since the gimbal analysis shows the gimbal's ability to isolate the flywheel from vehicle motions, which eliminates radial bearing loads to torque reactions. The passive lift magnets which support the weight of the rotor also reduce the axial preload requirement. Without these magnets, the preload would be increased by the weight of the rotor, $940 \mathrm{~N}$.

Bearing life is estimated by calculating the L10 life of the bearing and applying appropriate adjustment factors to the L10 life. Bearing lives for two operating conditions were calculated and then averaged together using Miner's rule [9]. The first operating condition, which is assumed to account for $95 \%$ of the flywheel's life, assumes a rotor speed of 16,100 $\mathrm{r} / \mathrm{min}$ with $24 \mathrm{Nm}$ of torque applied to the rotor. The speed condition relates to an $80 \%$ SOC that could possibly be set as a target SOC for the hybrid bus application. The torque at this speed is a conservative assumption which accounts for effects of rotor imbalances and small gimbal movements. At this condition, a bearing life of 107,000 hrs is calculated. The second condition accounts for the remaining $5 \%$ of the bearing life and assumes a rotor speed of 16,100 r/min with a $100 \mathrm{ft}-\mathrm{lb}$ torque applied to the rotor. This condition represents bus movements that transfer torque to the rotor, but are quickly dampened by the gimbal. At this condition, the bearing life is estimated to be 9,500 hours. By using Miner's rule, a final bearing life of $70,700 \mathrm{hrs}$ is calculated. If we assume that the flywheel were to operate 18 hrs a day, everyday, this life equates to a 10 year service life.

\section{Thermal Design and Analysis}

A thermal analysis was performed for the arbor flywheel design to evaluate the losses. The losses in this design result of motor-generator losses, aerodynamic windage losses, and bearing losses.

The stator windings of the motor-generator will be liquid cooled with a water glycol solution by discrete coolant passages embedded in the windings and back iron. A detailed design of the windings and coolant passages has not yet been performed, but estimates of motor-generator losses assume a 96\% efficiency, which translates into $5 \mathrm{~kW}$ per machine. A thermal cooling circuit has been sized to remove the $10 \mathrm{~kW}$ loss from both flywheels at an ambient air temperature of $45^{\circ} \mathrm{C}$. This cooling circuit contains a water pump to supply $15 \mathrm{~L} / \mathrm{min}$ flowrate and an air-to-liquid crossflow heat exchanger which will keep the coolant between $75^{\circ}$ to $85^{\circ} \mathrm{C}$.

In order to decrease the aerodynamic windage losses on the flywheel, operation in a vacuum is required. The pressure inside the housing will be maintained at 10 mTorr by a small vacuum pump. This pressure is low enough to minimize windage and be below the minimum breakdown voltage of the Paschen Curve. Aside from greater aerodynamic losses, operation at a higher pressure, such as 0.1 to 1 Torr, could be detrimental to the stator windings and result in an insulation breakdown. The windage calculations for the flywheel are based on a method that characterizes the slip flow regime and has been supported by test data [11]. At 18,000 r/min with slip flow conditions, the total windage loss is $95.3 \mathrm{~W}$.
The bearing losses are calculated by comparison of operating conditions to empirical data acquired by Draper Laboratories [12]. Tests were performed by Draper Laboratories on running ball bearings at high speeds in a vacuum for flywheel applications. Losses for a similar bearing application can be calculated by comparing operating speed, bearing dimension, and loads to empirical data provided. At full speed, 18,000 $\mathrm{r} / \mathrm{min}$, with $24 \mathrm{Nm}$ torque applied to the rotor, the total bearing loss is $140.6 \mathrm{~W}$.

A steady state axisymmetric thermal model was generated to evaluate the effect of windage and bearing losses on the arbor flywheel design. A key point in this thermal analysis is that the only means of cooling available to the rotor flywheel is radiation to the aluminum housing. Forced air convection at an ambient temperature of $45^{\circ} \mathrm{C}$ is applied to the outside of the stator housing. The inside of the aluminum housing will be anodized to increase the emissivity to 0.8. The composite naturally has a emissivity of 0.8 , but the steel structure of the arbor will require a coating to increase the emissivity to this value, which was used in the analysis. For the bearing and windage losses, a 50\% split was assumed between the rotor and housing.

At full operational speed, $18,000 \mathrm{r} / \mathrm{min}$, the bearings reach the maximum temperature in the model at $186^{\circ} \mathrm{C}$. The maximum temperature the composite reaches is $109^{\circ} \mathrm{C}$. These temperatures are within the operating limits of composites, which have been demonstrated to $160^{\circ} \mathrm{C}$ [13], and within the operating temperatures of commercial ball bearings and lubricants, which can operate at temperatures greater than $200^{\circ} \mathrm{C}$. This analysis also represents the worst case scenario, since the average speed of the flywheel during operation will be closer to 16,100 r/min, which represents an 80\% SOC. At this speed, the windage and bearing losses drop to $76.3 \mathrm{~W}$ and $122 \mathrm{~W}$ respectively.

\section{E. Containment}

To ensure safe operation, a containment structure was designed around the arbor flywheel. Although the structural analysis has shown the rotor components to operate well within material limits, containment must be provided to safely dissipate the kinetic energy in the event as a bus crash.

Containment of the flywheel is accomplished by a three part system aimed at absorbing the flywheel's kinetic energy, Fig. 9. The first containment layer is the $12.7 \mathrm{~mm}$ thick aluminum vacuum housing of the flywheel motor-generator. Surrounding

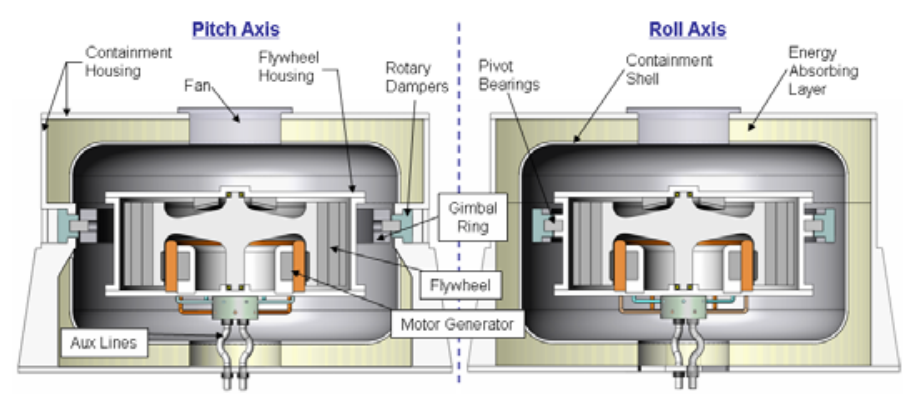

Figure 9: Containment structure for arbor flywheel 


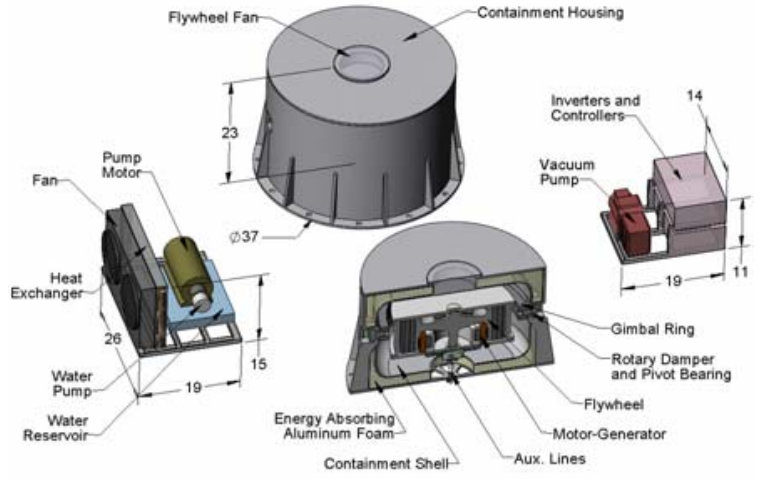

Figure 10: Complete flywheel energy storage system

the flywheel and gimbal is a steel containment shell. Outside of the containment shell is a thick energy absorbing layer. This layer will consist of a metallic honeycomb or metallic foam structure. The containment adds $235 \mathrm{~kg}$ to the mass of each flywheel.

\section{F. System Components}

The complete flywheel energy storage system, with auxiliaries is shown in Fig. 10. The system auxiliaries include inverters and controllers for the motor-generators, liquid cooling circuit, and a vacuum pump. Each flywheel with gimbal and containment has a mass of $390 \mathrm{~kg}$. The auxiliaries add an additional $80 \mathrm{~kg}$ to system weight. The total system mass would be $860 \mathrm{~kg}$ with a volume of $1 \mathrm{~m}^{3}$.

\section{CONCLUSION}

A complete flywheel energy storage system has been presented for a fuel cell powered hybrid bus. The flywheel had been sized to meet the energy storage and power requirements for a fuel cell powered bus, as determined by vehicle simulations on an actual urban route in Austin, Texas. The flywheel system described can provide $240 \mathrm{~kW}$, with delivered energy of $1.87 \mathrm{kWh}$ using a 75\% DOD. One of the largest costs from previous flywheel designs results from magnetic bearings which are required for higher speeds and energy density. This flywheel design can deliver the required energy for the fuel cell hybrid bus predicted by PSAT simulations, and design analysis shows adequate bearing life is achieved with less expensive rolling element bearings.

Ultracapacitors, which are commercially available, are able to provide some of the same benefits as a flywheel energy storage system. The primary benefit that both energy storage options can provide, when compared to chemical batteries, is increased power densities. With respect to energy storage capability and power densities, ultracapacitors and flywheels are comparable. The one benefit of flywheels is there is no performance degradation throughout the life of the flywheel. Over a ten year operational life, ultracapacitors can lose $20 \%$ $30 \%$ capacitance operating at room temperature, which directly translates into loss of energy storage capability. Furthermore, every additional $10^{\circ} \mathrm{C}$ rise in temperature doubles the rate of degradation [14].
The lifetime limits on the flywheel system described are primarily due to the rolling element bearings for a 10 year service life. After 10 years of service the bearings can be replaced to extend the life of the flywheels. Since the physical mass of the flywheel is the energy storage mechanism, there is no degradation in energy storage capability over the life of the flywheel. In addition, the motor-generator which powers the flywheel would have little to no degradation in performance capability over the life of the machine.

\section{ACKNOWLEDGMENT}

This work was performed under funding from the U.S. Department of Transportation - Federal Transit Administration and managed by the Center for Transportation and the Environment. Their support of this program is greatly appreciated.

\section{REFERENCES}

[1] Dr.ir.F.J.M, Thoolen, “General Information on CCM's Flywheel Technology,” http://www.ccm.nl/pdf/FLW-Tech-160204.pdf.

[2] Fraunhofer Institut Verkehrs und Infrastruktursysteme, “AutoTram: Technologies for Mobility and Sustainability in the Future,” http://www.ivi.fraunhofer.de/frames/images/autotram/Autotram_RollOut. pdf.

[3] M.M. Flynn, J.J. Zierer, and R.C. Thompson, "Performance Testing of a Vehicular Flywheel Energy System,” 2005 SAE World Conference, Detroit Mi. April 11-14, 2005.

[4] E.P., Furlani, "A Two-Dimensional Analysis for the Coupling of Magnetic Gears,” IEEE Transactions on Magnetics, Vol. 33, No. 3, pp. 2317-2321. May 1997.

[5] Yao, Y. D., D. R. Huang, C. C. Hsieh, C. Y. Chiang, S. J. Wang. Simulation Study of the Magnetic Coupling Between Radial Magnetic Gears. IEEE Transactions on Magnetics, Vol. 33, No. 2, pp. 2203-2206. March 1997.

[6] Rasmussen, P. O., T. O. Anderson, F. T. Jorgensen, O. Nielsen. Development of a High-Performance Magnetic Gear. IEEE Transactions on Industry Application, Vol. 41, No. 3, pp. 764-770. May/June 2005.

[7] G. Genta, "On the Optimum Design of a Steel Flywheel for a Hybrid City Bus,” Proceedings Intersociety Energy Conversion Engineering Conference, 20 ${ }^{\text {th }}$. Miami Beach FL., 1985.

[8] Alloy Digest, “Ferrovac 4340,” ASM International 2002.

[9] R.C. Juvinall, K.M Marshek, "Fundamentals of Machine Component Design,” $3^{\text {rd }}$. ed. John Wiley \& Sons, Inc., New York, 2000.

[10] B.T. Murphy, D. A. Bresie, and J. H. Beno. "Bearing Loads in a Vehicular Flywheel Battery." Electric and Hybrid Design Studies, Proceedings of the 1997 International Congress and Expostion. Detroit, MI: Feb 24-27, 1997.

[11] H.P. Liu, M.D. Werst, J.J. Hahne, and D. Bogard, "Prediction of Windage Losses of an Enclosed High Speed Composite Rotor in Low Air Pressure Environments,” ASME Summer Heat Transfer Conference, Las Vegas, NE, July 21-23, 2003.

[12] Coco, R., H. Singer. Ball Bearing Application to a High-Speed Flywheel. Draper Laboratory. Presented to the Flywheel Energy Storage Technology Workshop. Oak Ridge, TN. 2 - 4 November 1993.

[13] B. Rech, J.J. Granier, and R.C. Thompson, "Mechanical Properties of T1000G CFRP with Varying Resin Concentration,” Classified Seminar on Applications of Electromagnetic Launch Technology, Washington DC, 2-4 May 2007.

[14] Dispennette, John. Power Management Design: How Do I Feed My Power Needs? A Look at Ultracapacitors. Maxwell Technologies. July 18, 2005. 